2016-10-03

Neoliberalism and the (internal) marketisation of primary school assessment in England

\title{
Pratt, Nicholas
}

http://hdl.handle.net/10026.1/4764

\subsection{2/berj.3233}

British Educational Research Journal

Wiley

All content in PEARL is protected by copyright law. Author manuscripts are made available in accordance with publisher policies. Please cite only the published version using the details provided on the item record or document. In the absence of an open licence (e.g. Creative Commons), permissions for further reuse of content should be sought from the publisher or author. 


\title{
Neoliberalism and the (internal) marketization of primary school assessment in England.
}

\section{Nick Pratt}

Plymouth University, Institute of Education, Drake Circus, Plymouth, PL48AA

\section{nick.pratt@plymouth.ac.uk}

\begin{abstract}
This paper considers the effect of recent education policy on assessment practices in English primary schools and how these affect relationships between teachers and pupils in an increasingly marketdriven school system. Previous research has focused largely on the effect of markets at a systemic level, but less attention has been paid to how marketization plays out in teachers' work at classroom level. Similarly, research on assessment has tended to examine teachers' practices in relation to pupils' learning rather than examining it in terms of the role it plays in teachers' professional working lives. This paper brings these ideas together, using the latter as the context for understanding the former. In particular it focuses on recent policy changes to the way schools in England are evaluated, moving from final attainment to pupils' progress 'in-year', and considers their potential for altering the dynamics within schools rather than just between them. It draws on a small-scale, interpretive empirical study involving interviews with primary teachers in England. Data from this study are used to illustrate how tensions can arise for teachers and how internal market competition can be set up between them in which pupils' achievements become a commodity to be made use of, encouraging teachers to consider pupils' achievements as private, rather than public, goods. The paper thus provides a starting point for exploring the effect of market-orientated education policy on teachers' assessment practices at the in-school level and briefly examines some of the implications of this effect.
\end{abstract}


Neoliberalism and assessment - Pre-referee Version

\section{Introduction}

In the last 30 years, social policy in many western societies has become more and more dominated by ideologies founded in various forms of neoliberalism. Education has been no exception and during this period schooling has increasingly been constructed in market terms. This marketization is particularly prevalent in the Anglo-American school systems, though steadily elsewhere too (Rutkowski, 2007; Sahlberg, 2011) and a lot has been written about its effects internationally in relation to, for example: commercialism and private businesses (Ball, 2004; Ball, 2009); mechanisms for coercive state governance (Lipman, 2013); parental choice of schools (Ball, 2003; Ball, Bowe \& Gewirtz, 1995); the management of performance of teachers (O'Leary, 2012); and the effect on educational practice itself (Connell, 2013). At a more fine-grained level, Stevenson and Wood (2014) have considered the 'pincer movement of markets and managerialism that have combined to effectively and radically reshape teachers' experience of work' (p.46). However, whilst research has largely addressed the effect of markets on schooling at a systemic level, less attention has been paid to how marketization plays out in teachers' work at the level of the classroom, and in particular in terms of their professional standing. One notable exception in this respect is Gillborn and Youdell (2000). Their case study of two English secondary (11-16 yrs) schools provides a close analysis of the way in which pressure to achieve better and better test outcomes at 16 permeated through all of the schools' activities and 'set up a series of interlocking constraints acting upon schools, teachers and pupils' (p.33).

Here I develop an argument along the same lines but in the context of primary (5-11 yrs) education and contemporary policy in England, examining how 'the market', as it relates to the system of schooling described above, plays out for primary teachers and pupils. To illustrate the argument I draw on a small-scale empirical study involving interviews with teachers focused on their experience and understanding of their assessment practices. The choice of assessment as the focus reflects the central role that it now plays in English schools; it is through assessment practices that teachers" success, or lack of it, is largely defined. Whilst a great deal of research has been carried out looking 
Nick Pratt

at the practice of assessment and its effect on pupil outcomes (e.g. Cooper \& Dunne, 2000), as well as at the validity and reliability of testing to measure these, little has been done to examine it from a social perspective in terms of the role it plays in teachers' working lives.

The paper takes the following shape. First, it considers the increasingly market-driven and normative context within which education operates. Then, having laid out this general picture, it notes that whilst attention has tended to focus on the idea of 'the market' in terms of competition between schools, recent changes to the way teachers and schools in England are judged have altered the dynamics within schools too. In doing so it makes use of a framework constructed from Michael Apple's (2005) observations about such marketization to explore the particular effect of two important policy changes relating to assessment: (i) a move from measuring pupils' attainment at the end of schooling to pupil 'progress' within and across years; and (ii) a corresponding move towards measuring teachers' performance using these outcomes. These, it is argued, have altered the relationship between teachers and between teachers and pupils, forcing them to undertake their work in particular ways. The concluding section then considers some of the implications of this situation for both teachers' and pupils' experiences of schooling.

\section{Global marketization and the English school landscape}

In England, as elsewhere, the mantra of successive governments over at least the last 20 years has been the need to 'raise standards'; in effect to ensure that test scores rise for 11 year-olds and 16 year-olds - the two ages at which tests are made public and for which schools are held accountable. The result has been a school system, and particularly an assessment system, which has become increasingly techno-rational in outlook. English teachers teach within a tightly controlled set of parameters, some made explicit in national curricula and national strategies, and others implicit but no less real for teachers - in the way pupils are regularly tested and the results used to make judgements about both learning and teaching. The Office for Standards in Education, Children's Services and Skills (Ofsted) which inspects schools also exerts considerable control over what is seen as legitimate, both in terms of outcomes and teaching/learning activity. 
Neoliberalism and assessment - Pre-referee Version

Since at least the mid-90s successive UK governments' trust has been placed in the idea that a rise in test scores - progress, in the sense above - is best driven by the creation of an education market. (Note that whilst the UK government is referred to here, the work applies only to schools in England since decisions about educational provision are devolved to regional governance in Scotland, Wales and Northern Ireland.) This market is part of a wider adoption of a neoliberal approach to managing public services; not that neoliberalism itself has stood still or represents a single ideological position. Furlong (2012) argues that there have been at least two successive versions of it at play over this period. Firstly, came New Labour's belief in a 'managed' market (actually started under the previous Conservative government) with centralised control of national strategies, most prominently in mathematics and literacy (Department for Education and Employment, 1998; Department for Education and Employment, 1999), taking control for the first time ever in England of how to teach as well as what to teach. Second, came the Conservative/Liberal Democrat coalition's more liberal freedom in which the market alone was allowed to work on raising standards as measured by test scores - an increasing freedom that shows no sign of abating under the current Conservative government. Moreover, Apple (2004, p.23) suggests that

neo-liberal visions of quasi markets are usually accompanied by neo-conservative pressure to regulate content and behaviour through such things as national curricula, national standards, and national systems of assessment.

Within the recent regimes, this neo-conservative pressure has pushed to the fore particular values associated with a largely traditional vision of education, and created a situation in which

at the same time as the state appear[ing] to be devolving power to individuals and autonomous institutions which are themselves increasingly competing in a market, the state remains strong in key areas. (ibid.)

In England these areas include tighter and more specific versions of 'outstanding teaching' which are policed by an inspection system in which the driving mechanism is the assessment of pupils' test 
Nick Pratt

outcomes (Stevenson \& Wood, 2014). For anyone not associated with education in English schools it may be hard to appreciate just how much of a hold this assessment-driven culture has over the lives of those who work in them; to a large extent it dominates the way they think and talk about their work, with assessment data being used as a proxy for the overall standard of education in a highly politicised landscape. The term 'progress' has been adopted by successive governments and policy makers to stand for the rise in pupils' attainment over time. Pupils' progress over stages of their educational life against centrally defined levels of performance has become the key measure by which schools have been judged during inspection. Schools can only be graded as 'outstanding' by Ofsted if the progress from Key Stage 1 (KS1 - 7 years old) to Key Stage 2 (KS2 - 11 years old) fits the approved pattern, regardless of the perceived quality of teaching during an inspection. Within this system the quality of teaching is understood to be validly and reliably represented by the measured progress. In turn this means that teaching tends to get constructed backwards; if the progress is not as much as it should be then teaching cannot be good, regardless of what is seen on the ground. Furthermore, the UK government has recently introduced new arrangements for performancerelated pay for individual teachers (Hodgson, 2012) in which successful teaching gauged at an individual level is defined as all pupils making a specific amount of progress across a year, regardless of circumstances. Assessment is therefore a central element of teachers' everyday discourse.

\section{The empirical study}

To explore the role that assessment plays in teachers' working lives and the relation this has with the policy landscape, individual interviews were undertaken with 12 primary key stage 2 (KS2: 7-11yrs) teachers from 4 different schools in the SW of England. These interviews were semi-structured, using open ended questions designed to elicit 'accounts of' what teachers did around assessment before asking them to 'account for' these actions (see Mason, 2002) in terms of the way they fulfilled professional expectations, systemic requirements or personal aims. For example, the interviewer opened each interview by asking the interviewee to 'tell me what you do for assessment in this school' before following up the response in a way that asked him or her to account for these 
Neoliberalism and assessment - Pre-referee Version

actions in some way. This approach is based on the premise that all social activity is goal-orientated (Vygotsky, 1978) - though each 'goal' might be implicit to the actor and entirely embodied in their action rather than propositional. Beginning with 'what happened' allows the interviewee to consider their action in the context of their professional life and to account for it. Epistemologically, the project is therefore rooted in a view of the world in which meaning is social constructed. There is no claim to the 'truth' of the accounts therefore; rather, the claim is that they are trustworthy in as far as they account plausibly and convincingly for each person's actions.

Each interview lasted between 50 minutes and an hour and half, generating around 15 hours of recordings. Where appropriate teachers were also asked to share any materials that related to assessment, for example personal records or pupil tracking systems. Interviews were transcribed and the analysis was carried out following Charmaz (2006) through repeated reading of the data leading to the construction of themes. These were grounded in the data but nonetheless constructed by the researcher in light of the ongoing, developing ideas from the project and the overall aim of understanding teachers' work in terms of market orientation. The teachers were chosen opportunistically, in as far as having approached the school it was left for individuals to choose to participate or not, but as far as possible they were selected to represent a span of pupil ages across KS2, stages of career, gender and professional role. In what follows quotes are all taken from the interviews and the first reference to each teacher shows their profile in the following format: (Age/Years teaching/Current age group/Other information) so that, for example, Kim, who is mid-30s, has 15 years teaching experience, currently works with Y5 and is also the special educational needs coordinator at the school is shown as 'Kim (mid-30s/15/9-10/SENCo)'. All names are pseudonyms and more generally the project was guided by an ethics protocol in line with the British Educational Research Association guidelines and approved by the author's employing university ethics committee.

\section{Theorising teachers' work in market terms}


Nick Pratt

In relation to the marketization of public services as a whole, Apple $(2005$, p.12) claims that transforming them is not easy and requires work on at least the following premises which (with the order changed slightly from the original) provide the framework for the analysis that follows.

1. The services or goods that are to be focused upon must be reconfigured so that they can indeed be bought and sold.

2. The working conditions and outlook of the employees who work in this sector must be transformed from a model based on collective understandings and providing service to 'the public' on the one hand to working to produce profits for owners and investors and subject to market discipline on the other.

3. People who received these [services or goods] from the state must be convinced to want to buy them.

It is important to be clear that I am not suggesting that assessment practices at the classroom level actually represent 'a market' in these terms. Clearly, no direct buying and selling takes place at the classroom level, but using Bourdieu's notion of 'capitals' (Bourdieu, 1986; Bourdieu \& Wacquant, 1992) allows the development of the idea of market exchange involving teachers, pupils and schools as a way of illuminating aspects of their school lives. In this sense, each party is able to acquire capital in Bourdieu's (ibid.) terms: symbolically, in terms of the grades of measured outcomes; culturally, in terms of their position in the educational field; and, even economically in terms of pupils' value to schools and the potential for teachers to acquire pay rises in line with the performance in their assessment outcomes (see below). The intention then is to demonstrate how the general orientation towards neoliberal/neo-conservativism within the system as a whole, represented in terms of the three premises above, is changing the nature of teachers' assessment practices and the relationship with their pupils and, furthermore, that this can be understood in terms of marketization as a whole. From this perspective teachers' capital is understood as being acquired through their work in the field, here the social arena within which the work of school 
Neoliberalism and assessment - Pre-referee Version

assessment is undertaken. This, as Colley (2014, p.669) notes, is 'a space of conflict and competition constructed only through the human doings of human people' so that it 'is not only a set of external conditions which themselves have been devised or imposed ... [but] is also the agentic and partly subjective playing of the game through [their] habitus'. Field and habitus are not therefore separable; they are mutually constitutive of each other: habitus developed through repeated activity in the field; field developed through the playing out of activity through habitus. The generation and analysis of data here is therefore focused on how the changing nature of assessment as a high-stakes, politicised element of schooling affects the ways in which teachers (and pupils) 'play out' schooling. In this respect, two other ideas are relevant from Bourdieu's work: doxa which refers to the dominant discourse of a field, separating what is thinkable from what is unthinkable; and illusio, a more conscious belief in the stakes (enjeux) of the game and the belief that it is worth playing. Where doxa is a non-conscious participation in the dominant discourses of a field, illusio is a more aware sense of 'simply acting sensibly' (Colley, 2014, p.670) in relation to the stakes of the game. By acting this way teachers implicitly say to themselves that they will be able to achieve things of value, and these may even outweigh acts of symbolic violence that they experience as a result.

\section{Premise 1: Reconfiguring learning and assessment as commodities}

Teachers' use of assessment to classify and construct children differentially, is well established (e.g. Boaler, Wiliam \& Brown, 2000; Bradbury, 2012; Cooper \& Dunne, 2000; Gillborn \& Youdell, 2000; Kelly et al., 2013; Solomon, 2007); as is pupils' complicity in this process, Walter Doyle noting some 30 years ago that teachers and pupils appeared to swap grades for good behaviour (Doyle, 1986). However, in the current climate there are also differences. Whereas before such exchanges took place in the private space of classrooms as a transaction between teachers and pupils, now, more than ever, teachers must make them visible as just one aspect of the range of competing imperatives (Alexander, 1992) which shape their teaching. As Connell $(2013$, p.101) notes, '[l]n an "audit society", public institutions have to make themselves auditable, on a model imported from business accountancy' and this imperative of empiricism demands that their practice shows, 'a 
Nick Pratt

constant production of evidence that you are doing things 'efficiently' and in the 'correct' way' (Apple, 2005, p.15). The embodiment of these observations is illustrated perfectly by Rob (early20s/3/7-8) who explains that,

the comments that I write in the books, my marking comments, should hopefully show what the child has achieved in that lesson, so that should be written down as part of my comment and the next step should also be written down as part of my comments. So if anybody were to pick their book up and flick to a particular page and read the comments it would be clear what my assessment of the work was through what l'd written and the comments underneath that particular piece of work. (Rob)

In being required to conform to increasingly normalised expectations, teachers are having to make their work more accountable. To do so they have to make what they do more visible, in order that it becomes measurable. Thus, one aspect of neoliberal professional life is the changing emphasis from practice which is effective to practice which has the hallmark of effectiveness. For example, after describing his marking approach (above) Rob goes on to note that

when I'm writing a comment, me and the child are not the only people who are going to be looking at that book so whatever comment I write, whatever assessment of the piece of work I show, would have to be something that I would be happy for the headteacher to pick up, or for a book scrutiny to see, or Ofsted to see, or parents. ... So there's that professional level where you think yes I've got to show that I'm noticing this or I'm not noticing that, so I've got to show that I understand, that I know the next steps for that particular child and shown it in my marking comments.

Schooling thus demands of teachers engagement in a doxa of performativity in which they must do accountability work; that is, they must act in particular ways which are valued within the school system and make these visible to others. Rob's marking is, as he says, not simply a process of making sense (of pupils' understanding) but the construction of an artefact, a process 'of reification, that is 
Neoliberalism and assessment - Pre-referee Version

the transforming of human properties, relations and actions, into things independent of persons and governing their lives' (Ball, 2004). In addition to Rob's marking practices, other examples abound in English schools; one hears that a teacher 'got an outstanding' for a lesson being observed, or that their work is focused on 'the children's learning' (as opposed to on 'children learning'). Such reification is, as Wenger (1998) points out, a feature of all social practice in giving form to understanding and providing a focus for the negotiation of meaning. However, it is not just about giving form to ideas. Much of what the teachers described about their practice involved enumerating these ideas so that they can be measured and audited in some way, usually 'a termly meeting with the headteacher looking at your data' (Kim). It is not insignificant that English schools, their teachers and the surrounding advisors, inspectors and other stakeholders, refer to these scores as 'data'. In doing so, they are not simply implying that they constitute one form of data. Rather the very meaning of the term has been commandeered to ensure only that which is enumerated counts; as if data could only be numbers and not more qualitative descriptions of the pupils' world.

Although processes of education are therefore being transformed into objects with numerical value, as Stevenson and Wood (2014) make clear, as far as the notion of the market is concerned any assessment score

is not a value determined by the interaction of supply and demand in the traditional sense, and therefore it cannot be considered a traditional exchange value. Rather it might more accurately be presented as the quantification of a use value where the use value is determined by the state (p.49).

Whilst the services and goods of assessment practices are not therefore being reconfigured in order to be bought and sold directly they are nonetheless being reconfigured so as to be measurable with state-specified use value. Furthermore, this use value is not only about being 'useful' for the pupil. It is also to be 'used by', even 'used on', teachers in order to drive changes in school outcomes, such 
Nick Pratt

that Mark (mid-40s/10/8-9) describes a process of 'being beaten over the head with facts and figures' and Fiona (mid-20s/5/7-8) claims that:

we are all under increasing pressure to get the results, and I think year on year they expect more out of the same age of child, which um, sometimes isn't that realistic. But you're under pressure thinking, well I need to make sure that they achieve it because if I don't I'm failing. So I think it's quite um, heavy pressure.

Apple (2004, p.24) points out that this whole process of commodification and measurement is also 'ideally suited to the task of providing a mechanism for the neo-conservative attempts to specify what knowledge, values, and behaviors should be standardized and officially defined as legitimate'; as Tina (mid-40s/21/-/senior leader) says, 'as a school [you] need that data to justify what you are doing'.

\section{Premise 2: From public service to personal profit}

Of course test scores have always been important for schools to demonstrate at a general level how effective they are as institutions. However, prior to the current high-stakes, high-accountability testing regime in an education market, such assessment outcomes were essentially a public good. Such goods have two features: they are non-excludable, meaning that the benefit they offer is, at least to some extent, for everyone; and they are non-rivalrous, meaning that their 'consumption' by any one party (the school perhaps) does not prevent their use by another. As the market model has taken hold over the last 30 years, placing schools in competition with each other, so the public goods of pupil outcomes have become private goods for schools, owned exclusively by them for their own use and rivalrous in the way they are 'consumed' in the service of the competitive market environment.

However, in the interviews conducted for this study evidence abounds that teachers are increasingly seeing assessment data as a commodity for their own use too. Interviewees regularly referred to 'my data' and Sasha (mid-20s/6/9-10) claims that 'rarely does my own professional progress get 
Neoliberalism and assessment - Pre-referee Version

questioned in those [performance management] meetings [because] I suppose this year my children have made adequate or more progress'. Various forms of assessment are now being used not just to carry out the systemic work of the school as a whole, but as individual capital acquired by the teacher him/herself. Two policy initiatives, at least, press on the teacher in this regard. Firstly, since September 2013 national pay scales for teachers in England have been changed into a system based on 'linking all pay progression to performance' (Department for Education, 2013a, p.5). This has created a direct link between the symbolic capital of pupil grades and the potential cultural and economic capital for the teacher. Secondly, whereas previously pupils' outcomes were gauged almost entirely on attainment measured at key moments in their education, the focus now is on continuous 'pupil progress', measures of their movement up a ladder of assessed outcomes within a given time. The latter can be understood in terms of the former. Linking teachers' professional and financial rewards to outcomes requires the latter to be tracked on an annual basis, to accommodate the promise that 'school leaders are now free to reward their best teachers more than ever before with more autonomy to attract, retain and reward those teachers who have the greatest impact on their pupils' performance' (Gove, 2013). Performance is no longer just a function of schooling outcomes as a whole. The use of pupil progress positions it within a political doxa of 'continuous improvement'; the unarguable idea that provision for pupils by schools should improve smoothly and endlessly. Within this discourse, progress should be visible over timeframes as short as a single lesson, and certainly over the course of a half-term.

Crucially, these two issues are driving an important move; from pupils' success being a private good for schools to one in which it is increasingly becoming a private good for teachers individually too. This is true in both senses outlined above. Firstly, learning has become excludable at the classroom level. Despite contemporary learning theory since Vygotsky (1978) suggesting strongly that knowledge and learning might best be understood as historically and culturally situated, sociallyconstructed and distributed (Billett, 2001; Lave, 1991; Pea, 1993), the language of the school curriculum and the testing system demonstrate how in schools knowledge is firmly understood as 
Nick Pratt

epistemologically objective and as an individual possession, and learning as a form of acquisition (Sfard, 1998). Teachers such as Mark and Kim thereby refer to the practice of 'gap analysis' which 'pinpoints exactly what pupils know'. By understanding knowledge as objective and 'acquired' by the learner, credit for its acquisition can be attributed to particular teachers through acts of teaching. This commodification, turning learning from a verb into a noun and then attributing it to the direct effects of teaching, allows teachers to own it and thus to exclude colleagues from making use of its value too. Rob is thus able to assert that 'it does allow you to demonstrate with a score or a number if you are applying for jobs or for management and you can say well I've achieved X as a sort of nonarguable level of proof I suppose'.

In addition to learning becoming excludable, the move from measuring teacher performance in terms of pupils' final attainment to using progress across time makes learning potentially rivalrous. Whereas previously all staff in a school could share equally in the benefits of a child reaching the expected level at the end of his or her schooling (and conversely, share responsibility where they did not), now progress at one stage is a personal responsibility and success simply ups the ante for the next teacher. Progress made by any one particular child becomes capital to be acquired by the teacher in whose class it takes place, making it not just impossible for others to benefit from it (except in as much as the school as the whole is still accountable for final grades) but potentially intensifying the competition for such progress because of its scarcity as a resource. Tina summarises the dilemma for teachers, thus:

I think it does, it can cause tension. I know that in the past when I've been the year 5 teacher there is that year 6 teacher looking back at you and saying don't give me too many level $5 \mathrm{~s}$ because this is what I've got to do you know. It's that kind of feeling that you've got to move them on 3 points progress or a little bit more. But if it's too little it's not good enough from the school performing and if it too much the next teacher is saying hang on a minute, what can I do with them? 
Neoliberalism and assessment - Pre-referee Version

In this sense assessment generates competition which is internal to the organisation, in addition to that which is external between organisations. Whereas the latter has begun to alter the relationships between various stakeholders and school institutions (e.g. Ball, 2003; Lipman, 2013), internal competition seems likely to further alter the relationships between teachers themselves, and with their pupils. Sasha, for example, notes that 'there can be a lot of tension about it' and that 'there's questions of peoples' past assessment, whether it's accurate, whether their level judgments are secure, whether the same processes are happening'; whilst Rob suggests that 'just like the children, teachers have a range of personalities and some are going to be very competitive people who are driven by that'. Tony (early-30s/10/7-8) is more blunt about assessment: 'I'd use the word manipulation [laughs]! It is manipulated ... because of all the pressures'.

Superficially, this might imply that low attaining pupils are more valuable to teachers than those who already attain high grades, since there is more room to press progress out of them. However, the situation is more complicated than this. Firstly, though the focus of this paper is on assessment, professional life is multi-faceted and 'policy enactments happen in schools through complex processes of interpretation and translation' (Maguire, Ball \& Braun, 2013, p.336). I am certainly not implying that teachers' practice revolves only around pupil progress. However, pupils' success is increasingly important, as I have argued. Moreover, a growing body of research demonstrates that assessment is largely constructed by the school system itself, particularly through the concept of 'ability' (see, for example, Boaler, Wiliam \& Brown, 2000; Bradbury, 2012; Wilkinson \& Penney, 2013). Whilst low-attaining pupils might have the potential to rise further, this literature suggests that they also get constructed as 'being of low ability' and this tends to replicate itself as they move through the system (Wiliam \& Bartholomew, 2004). This allows Fiona to note, with reference to the extent to which pupil grades are allowed to be adjusted as they move from one teacher to the next, that

\section{F: I think it's more acceptable with some children than with others.}


Nick Pratt

INT: Because of ...?

F: Those that have got, that are seen to have especially special needs, it's alright to say they've slipped back this much, but perhaps if it's someone who's classed as 'brighter', for want of a better word, you, you know, that might not be well received.

Hence, the value of pupils is not in their raw scores but in the way the teacher, and the pupils themselves, view their potential capacity to make progress. It is therefore an issue of identification. In Wenger's (1998) terms it is the way in which teachers identify (objectify) them as potentially capable, and the way that pupils similarly identify themselves, that marks out their potential to make the right progress; a process that Gillborn and Youdell (2000) suggest is similar to medical 'triage'.

So whilst it's not directly the case that the teachers are changing their practice, according to Apple's second premise, 'from a model based on collective understandings and providing service to 'the public' on the one hand to working to produce profits for owners and investors and subject to market discipline on the other', they are in many ways being encouraged to think about their teaching as a personal act of 'profit-making'. These profits, in the form of pupils' grades, work for the school as a whole but also for the teachers individually, for example:

Mark: Ok, maybe I should play the game and maybe that $2 B$ could be a $2 A$ and if that $2 A$ is making me hit my performance management [target], maybe I should put it to a $2 \mathrm{~A}$.

Despite the rhetoric of use value of education for children moving into adulthood, the value of grades tends to drive at the production of numerical data which, in the sense outlined earlier by Stevenson and Wood (2014), is a quantification of something valued by the state for its own neoconservative political ends, so that Mark is aware that: 
Neoliberalism and assessment - Pre-referee Version

[working on pupils' social development] is something that maybe isn't quite definable. Ok, the [previous] teacher says 'cor, this lot are brilliant. I love them' but then that's not measured, it is just a pat on the back from the previous teacher for passing up a nice class.

\section{Premise 3: Illusio - engaging in the market game}

In relation to Apple's third premise there is nothing to 'buy' in any literal sense in teachers' relationships with pupil assessment. However, for the system to work the various stakeholders must come to believe that it is in their own interests to take a willing part in it, to demonstrate the 'impact' of their teaching in these terms and show that this impact is the 'right' one to fit the sacred story (Clandinin \& Connelly, 1995) of the political landscape. This is Bourdieu's notion of illusio, illustrated in the way teachers engage willingly, albeit to differing degrees, in the apparent meritocracy of teaching and assessment. Thus, for Sasha, on suggesting that her pupils' assessment scores demonstrate her success she feels able to say that I suppose it sounds big-headed to say. I suppose this year my children have made adequate or more progress. Yeah, I guess it is'. On the other hand Mark acknowledges that 'I don't think I'm a bad teacher; I just don't think I play the game as much as I should do, and maybe I'm too honest and sometimes that acts against me'.

Ironically, then, teachers may be given a false sense of agency by the commodification of pupils' outcomes. Whilst apparently providing a means of mapping each child's progress, it also locks them into seeing this journey only in terms of a limited number of accountable goods - literacy and numeracy in particular. Moreover, one effect of commodification is a process of abstraction such that commodities become ever more abstracted from their real use value as they instead take on exchange value, and ultimately only sign value. One question then is the extent to which pupils' efforts might undergo this effect; whether what starts to matter above all else is that the pupils appear successful, regardless of the extent of the use of anything they learn? Such a transition from direct focus on pupils' learning behaviours to a representation of these behaviours in the form of sign value of data is apparent in Kim's description of her termly performance review meeting: 
Nick Pratt

We have to go in and we analyse our class data so we say, right, the girls actually aren't doing particularly well on their reading and you need to focus on pupil premium children in your maths; what are you going to do to improve this data?

In the same vein, Tony notes that 'we don't take examples of work to these meetings, you just look at a sheet of data, which, you know, is um ... makes you feel like it's about your own performance rather than ...'

Caught in the tension between the importance of sign value for systems of accountability and of a genuine concern for the child, teachers may well experience tensions in their work. Their illusio is likely to be borne out of resolving this tension, having no choice but to put their faith in the numbers themselves as representative of something of 'real' use value for pupil, whereupon it becomes necessary to believe that the numbers being generated represent a change in something tangible for pupils themselves. However, whilst some might sense a deep unease about their work in these respects, it is possible that others remain unaware of these tensions at any explicit level. Such is the normative effect of neoliberalism (Connell, 2013) on the work people do, that teachers, particularly those who have come into the profession since the late 1990s, may no longer have a language for making sense of teaching in any other way. Thus Adam (early 20s/1/8-9), one year into career, seems quite happy to say that 'personally I think that performance related pay is a good thing'. Meanwhile, at the time of writing, the Department for Education has recently removed the externally imposed national levels, leaving schools to decide on their own ways to measure progress. Far from liberating Sasha to become even more 'successful', this removal of a national scale appears to represent a threat to her illusio because:

Sasha: In some respects it's a real shame that as of September there will be no generic nation-wide approach to assessment. I think it opens up a lot of gaps. I think it's good in some ways. It puts the onus back on schools and teachers to do what works for the school, 
Neoliberalism and assessment - Pre-referee Version

but I think having a nation-wide approach worked in terms of this is how we are counting it, this is what we are going to do, this is how we are going to do it.

INT: So, 'worked' in terms of what, in terms of ...

Sasha: In terms of everyone was essentially on a level playing field ... [and] ... you should be able to make comparative judgments between teachers in different schools

As Colley (2014, p.670) notes, 'changes in a field driven by powerful groups therefore often entail changes to its stakes' and moreover, change 'serves to marginalise and denigrate anyone who fails to identify with the new 'general interest' that has been manufactured as the only reasonable one' (ibid.). One wonders if, having invested in the 'reason' of national levels to make comparative judgments, Sasha might find herself marginalised by changes afoot; or else might manage to move with the times and find new ways to invest.

\section{Discussion}

Neoliberalism, manifested in terms of an educational marketplace, appears to be reaching its zenith in a number of countries globally and whilst in some there is a growing reaction to its effects, or perhaps simply the limits of its success even on its own terms, in England these effects have only recently started to be felt in full. The claim of successive English governments has been that marketization is a necessary and sufficient condition to make the kind of fundamental change to teachers' practice that is seen as essential for pupils' success. They define success in the only terms available in the neoliberal market they have created; the numbers associated with ever increasing test scores.

Whatever one thinks of its likelihood of success, like so much of recent policy under New Labour, Coalition and Conservative governments, the messages from recent changes are contradictory. On the one hand schools are being given more and more freedom to manage their own development with the ongoing drive for Academies and Free Schools, in which money is devolved directly to schools to buy services and develop teaching as they see fit. On the other hand there is a 
Nick Pratt

simultaneous tightening of control over what such development should look like; the appropriation of professionalism itself, as (Beck, 2008) has called it. In this regime, whilst every teacher is encouraged to work towards their own personalised areas of professional development, each must also mould themselves into the shape of the government prescribed Teachers' Standards (Department for Education, 2013b) since these 'set clear expectations about the skills that every teacher in our schools should demonstrate' (Gove, cited in Department for Education, 2013c). Furthermore, a central feature of education policy based on neoliberalism and neo-conservative values has been a belief in a system of meritocracy; everyone must be outstanding, but some will be more outstanding than others and rewarded accordingly. But such meritocracies have particular features. They are, by definition, based on individual success and personal endeavour. To gauge this and to reward it they must assume that learning is predictable, measurable and controllable through teaching. In this way teachers are forced to first commodify, and then assume responsibility for, pupils' learning in a very direct manner; but can, through their illusio, benefit from the manner in which pupil outcomes can be consumed and made excludable and rivalrous.

Of course from a neoliberal perspective the kind of competitive environment explored in this paper is seen to be a good thing - indeed it represents the driving mechanism for change that it posits as essential in the first place. A logical chain ensues to constitute the doxa of teaching and assessment: high-stakes testing and accountability in a market environment drive up standards of performance in teaching and this in turn raises pupils' outcomes, such that it becomes nigh on impossible to argue with Michael Gove's claim that 'great teaching can and does make a huge difference to children's performance' (Gove, 2013). Clearly, at one level this is true. Children do make progress in their schooling and competition between teachers can be seen to alter the way both parties perform. However, though small in scale, there is ample evidence in this study that teachers' work is increasingly 'a performance' in which assessment is not a benign activity for supporting pupils' learning but has also become a doxa of continuous justification of professional worth; 'a silent expectation of our headteacher or our leadership team' (Tina). But all this makes it increasingly likely 
Neoliberalism and assessment - Pre-referee Version

that we get a distortion - a manipulation, in Tony's words - of teaching practices in order that they do the right work for teachers themselves. In doing their assessment work teachers are required to shape 'their' pupil data into the right form, such that if

this is where they are now, in three weeks I need to prove they are here and that's got to be on some sort of formal sheet in my file somewhere, or saved on my [laptop] ... so if somebody asked me what I've done, you know, this is it, they didn't know that then but now they do (Tina)

What is in question therefore is how the nature of this 'performance' affects pupils' development, where it is seen in broader terms than simple test outcomes. In addition it raises questions about the relationships between teachers themselves and the nature of professionalism more generally; how pupils and teachers are constructed through this doxa as winners and losers in the schooling system and how this builds tensions and alliances between individuals. Whilst space has limited what can be said in this paper, further publications focus on how Tony's concerns about 'manipulation' are manifested in teaching and how pupils' outcomes are used to differentiate them in terms of their value in this process; or, as Fielding and Moss (2011, p.52) put it, how

the personal is used for the sake of the functional: students are included or excluded, valued or not, primarily on the basis of whether they contribute to the performance of the school.

\section{References}

Alexander, R. J. (1992) Policy and practice in primary education. London: Routledge.

Apple, M. W. (2004) Creating Difference: Neo-Liberalism, Neo-Conservatism and the Politics of Educational Reform. Educational Policy, 18 (1). pp 12-44.

Apple, M. W. (2005) Education, markets, and an audit culture. Critical Quarterly, 47 (1-2). pp 11-29.

Ball, S. J. (2003) Class Strategies and the Education Market: The Middle Classes and Social Advantage. RoutledgeFalmer. 
Ball, S. J. (2004) 'Education For Sale! The Commodification of Everything?'. [King's Annual Education Lecture 2004] Institute of Education, University of London.

Ball, S. J. (2009) Privatising education, privatising education policy, privatising educational research: network governance and the 'competition state'. Journal of Education Policy, 24 (1). pp 83-99.

Ball, S. J., Bowe, R. \& Gewirtz, S. (1995) Circuits of schooling: A sociological exploration of parental choice of school in social class contexts. The Sociological Review, 43 (1). pp 52-78.

Beck, J. (2008) Governmental professionalism: re-professionalising or de-professionalising teachers in England? British Journal of Educational Studies, 56 (2). pp 119-143.

Billett, S. (2001) Knowing in practice: re-conceptualising vocational expertise. Learning and Instruction, 11 (6). pp 431.

Boaler, J., Wiliam, D. \& Brown, M. (2000) Students' Experiences of Ability Grouping - disaffection, polarisation and the construction of failure. British Educational Research Journal, 26 (5). pp 631-648.

Bourdieu, P. (1986) 'The forms of capital'. in Richardson, J.E. (ed.) Handbook of theory of research for the sociology of education. Greenwood Press, pp 241 - 258.

Bourdieu, P. \& Wacquant, L., JD. (1992) An Invitation to Reflexive Sociology. Cambridge: Polity Press,

Bradbury, A. (2012) Education policy and the 'ideal learner': producing recognisable learner-subjects through early years assessment. British Journal of Sociology of Education, 34 (1). pp 1-19.

Charmaz, K. (2006) Constructing Grounded Theory: A Practical Guide Through Qualitative Analysis. Sage Publications.

Clandinin, D. J. \& Connelly, F. M. (1995) Teachers' professional knowledge landscapes. New York: Teachers College Press.

Colley, H. (2014) What (a) to do about 'impact': a Bourdieusian critique. British Educational Research Journal, 40 (4). pp 660-681.

Connell, R. (2013) The neoliberal cascade and education: an essay on the market agenda and its consequences. Critical Studies in Education, 54 (2). pp 99-112.

Cooper, B. \& Dunne, M. (2000) Assessing children's mathematical knowledge : social class, sex and problem-solving. Buckingham: Open University Press. 
Neoliberalism and assessment - Pre-referee Version

Department for Education (2013a) Departmental advice. Reviewing and revising your school's approach to teachers' pay. London: Crown Copyright.

Department for Education (2013b) Teachers' Standards. London: Crown Copyright.

Department for Education (2013c) Teachers' Standards. How should they be used? London: Crown Copyright.

Department for Education and Employment (1998) The National Literacy Strategy: a framework for teaching. London: Department for Education and Employment.

Department for Education and Employment (1999) The National Numeracy Strategy. Framework for Teaching Mathematics from Reception to Year 6. London: DfEE Publications.

Doyle, W. (1986) 'Classroom organisation and management'. in Wittrock, M. (ed.) Handbook of research on teaching. New York: Macmillan.

Fielding, M. \& Moss, P. (2011) Radical Education and the Common School: A Democratic Alternative. London: Routledge.

Furlong, J. (2012) Globalisation, Neoliberalism, and the Reform of Teacher Education in England. The Educational Forum, 77 (1). pp 28-50.

Gillborn, D. \& Youdell, D. (2000) Rationing education: Policy, practice, reform, and equity. Buckingham: Open University Press.

Gove, M. (2013) 'Why there has never been a better time to be a teacher.', Policy Exchange. London Department for Education,.

Hodgson, D. P. (2012) School teachers review body: twenty-first report. London: Crown Copyright.

Kelly, P., Pratt, N., Dorf, H. \& Hohmann, U. (2013) Comparing Pedagogy in Mathematics in Denmark and England. European Educational Research Journal, 12 (4). pp 553-567.

Lave, J. (1991) 'Situated learning in communities of practice'. in Resnick, L., Levine, J. and Teasley, S. (eds.) Perspectives on socially shared cognition. Washington DC: American Psychological Association, 44.

Lipman, P. (2013) Economic crisis, accountability, and the state's coercive assault on public education in the USA. Journal of Education Policy, 28 (5). pp 557-573. 
Nick Pratt

Maguire, M., Ball, S. J. \& Braun, A. (2013) What ever happened to ...? 'Personalised learning' as a case of policy dissipation. Journal of Education Policy, 28 (3). pp 322-338.

Mason, J. (2002) Researching your own practice. The discipline of noticing. London: RoutledgeFalmer.

O'Leary, M. (2012) Surveillance, performativity and normalised practice: the use and impact of graded lesson observations in Further Education colleges. Journal of Further and Higher Education, 37 (5). pp 694-714.

Pea, R. (1993) Learning scientific concepts through material and social activities: conversational analysis meets conceptual change. Educational Psychologist, 28 (3). pp $265-277$.

Rutkowski, D. J. (2007) Converging us softly: how intergovernmental organizations promote neoliberal educational policy. Critical Studies in Education, 48 (2). pp 229-247.

Sahlberg, P. (2011) Finnish Lessons. New York: Teachers College Press.

Sfard, A. (1998) On Two Metaphors for Learning and the Dangers of Choosing Just One. Educational researcher, 27 (2). pp 4-13.

Solomon, Y. (2007) Experiencing mathematics classes: Ability grouping, gender and the selective development of participative identities. International Journal of Educational Research, 46 (1-2). pp 8-19.

Stevenson, H. \& Wood, P. (2014) Markets, managerialism and teachers' work: the invisible hand of high stakes testing in England. International Education Journal: Comparative Perspectives, 12 (2). pp 42-61.

Vygotsky, L. S. (1978) Mind in Society: The Development of Higher Psychological Processes. Harvard University Press.

Wenger, E. (1998) Communities of practice: learning, meaning and identity. Cambridge: Cambridge University Press.

Wiliam, D. \& Bartholomew, H. (2004) It's not which school but which set you're in that matters: the influence of ability grouping practices on student progress in mathematics. British Educational Research Journal, 30 (2). pp 279-293.

Wilkinson, S. D. \& Penney, D. (2013) The effects of setting on classroom teaching and student learning in mainstream mathematics, English and science lessons: a critical review of the literature in England. Educational Review, 66 (4). pp 411-427. 
Neoliberalism and assessment - Pre-referee Version 